\title{
DLC1 wt Allele
}

National Cancer Institute

\section{Source}

National Cancer Institute. DLC1 wt Allele. NCI Thesaurus. Code C52070.

Human DLC1 wild-type allele is located within 8p22 and is approximately $432 \mathrm{~kb}$ in length.

This allele, which encodes rho-GT Pase-activating protein 7 protein, is involved in

cytoskeletal remodeling and negative regulation of cell growth. Loss of DLC1 gene

expression due to deletion and/or hypermethylation is associated with certain types of cancer including breast cancer, hepatocellular carcinoma, gastric cancer and non-small cell lung carcinoma. 